\title{
Development of an EIA screening phase for biogas projects in Latvia
}

\author{
J. Pubule, I. Bergmane, D. Blumberga \& M. Rosa \\ Institute of Energy Systems and Environment, \\ Riga Technical University, Latvia
}

\begin{abstract}
One of the main priorities among European Union member states is to promote renewable energy. Latvia also has to comply with the European Parliament and Council Directive 2009/28/EC on the promotion of renewable energy initiated on 23 April 2009. The directive states that the share of renewable energy has to reach $40 \%$ of total final energy consumption by 2020. Part of this share can be achieved with the energy produced by burning biogas in cogeneration plants.

Each domestic activity generates an environmental impact. Before the activity commences, the potential impact of activities has to be assessed. One of the tools that is widely used and is included in the Latvian legislation is the Environmental Impact Assessment (EIA). Environmental impact assessments are applied to different objects, where there is a risk that the construction or operation may have a negative impact on the environment, as well as on human health.

According to Latvian legislation, the activities, depending on their potential impact, are divided into two parts: the activities for which an EIA has to be completed and activities for which a screening has to be performed. The aim of the screening is to evaluate whether the activities can cause significant effects on the environment. Solely on the basis of the results of the screening a decision is made whether to perform the EIA procedure or not. The definition of the significance of the impact is essential. The defined criteria in the European Union legislation are included in the legislation of Latvia. The criteria specify the minimum range of points to be covered during the screening.

Biogas production through anaerobic digestion is considered as one of the most successful methods of dealing with increasing environmental pollution. Heat and electricity are produced by burning biogas in cogeneration plants. A wide variety of inputs can be used to produce biogas: livestock manure, crop
\end{abstract}


residues, sewage sludge, household and catering organic waste and energy crops. Simultaneously the production of biogas from organic waste also addresses the matter of the disposal of waste products. Waste that would otherwise be considered unusable, has now found a second life in the production process of the biogas. Given that until 2020, the share of renewable energy in Latvia has to be increased, it can be expected that in the coming years the amount of biogas production and combustion plants will increase.

Keywords: EIA, screening, biogas projects, renewable energy, impact significance, Latvia.

\section{Introduction}

The aim of the screening phase is to determine if the project must be subject to an EIA. Without this verification some actions can be evaluated very precisely while others can be forgotten or ignored. While carrying out an effective assessment a list with the activities planned, accompanied by the values and criteria for determining whether action should be evaluated, are formed $[1,2]$.

Categories of activities which are compulsorily required to carry out an EIA are defined in annex 1 of the EIA directive. In annex 2 of the directive, the operations that need to be undertaken in the EIA procedure on a case by case basis are defined. There may also be activities that are not included in these annexes, but the responsible organization of government after the screening has to decide to grant the EIA procedure to the activity. The state may also establish stricter limits, allowing certain projects to be subject to EIA procedure. The EIA procedure can also be made on a voluntary basis as an important step in developing the project [3].

Despite the fact that the EIA directive defines a uniform screening process, each country has implemented the EIA directive differently. Together with significant differences in regulations and practices of the initial inspection, the main shortcomings which have emerged are: doubts on the effectiveness of certain criteria and limits of systems for projects in annex 1, non-systematic approach for verification of projects in annex 2, large differences in the initial test criteria between member states, the lack of clear definitions of the types of projects leading to possible misinterpretation of daily practice. Criteria that define the level of significance of the project vary depending on the quantitative or qualitative assessment. Predestined criteria are based on thresholds or previously taken measurements and specified restrictions and limits existing in laws, rules and other guidelines. Criteria based on the judgment are applied, if the project is unlikely to have a significant impact, but in the context the need to take precautions is justified.

Four types of approaches to the initial verification can be distinguished:

1. Pre-trial or preliminary environmental assessment - the need of an EIA is seen through the early assessment process for projects of any type, under any circumstance. 
2. Each individual case - the need of an EIA is assessed individually for each project. This approach is usually used in conjunction with another method as its complement, for example, the list of projects or thresholds.

3. The list of projects - the need for an EIA is based on the lists of projects divided into different categories and types. There are two types of lists positive and negative. Positive lists specify the projects that need an EIA, the negative lists show exceptions.

4. Thresholds - the need for an EIA is based on the specific measures and restrictions of pre-defined criteria. These criteria may be differences in the size of the project, the particular location, as well as other criteria [4].

\section{The screening in Latvia}

In Latvian legislation, activities that must be carried out in environmental impact assessment are clearly defined, as well as the scope of the work, which is carried out in accordance with international treaties, is clearly defined. At the same time groups of activities subject to the screening are not well defined in the Latvian legislation, as well as the screening thresholds and criteria for evaluating the potential impact of the activity are not clearly defined. This leads to a very wide field of subjective judgments and indecisive approaches. By unreasonably reducing the number of projects which are subject to EIA procedure the public's right to engage in discussion becomes limited and it is not possible for the public to comment on a project. The lack of laws, regulations and guidance complicates the decision-making and leads to conflict and makes it possible to use the lack of structure within the laws for selfish purposes.

According to the legislation, the application of the initial planned actions is filed at the regional environmental administration of the State Environmental Service, depending on the location of the planned activity. The regional environmental administration evaluates the material concerning the proposed project and decides whether it is necessary to perform a screening. By evaluating the laws and regulations, it was found that The Cabinet of Ministers of the Republic of Latvia has determined the order in which the screening of the environment is completed for the proposed action. The application procedures and application content is defined in the legislation.

According to Latvian laws and regulations on screening, the regional environmental administration is entitled to invite experts to evaluate, request and receive information from state and local government institutions, as well as to request and receive additional information from the project proposer. However, given the current economic situation, the government is not able to invite experts because there are no resources for the remuneration of experts [5].

It is not possible to precisely define what is considered to be a significant impact on the environment. In the majority of the developed countries, where the EIA procedure is introduced, various methodological tools are developed to aid, so uniform potential of environmental impact evaluation in the screening process of proposed action could be made and a decision as to whether the activity 
should complete an environmental impact assessment procedure could be taken. In most cases, such aids are made as questionnaires or a matrix.

The criteria of the significance of the impact include the description of the threshold value for identification [6]. The threshold values in Latvia are environmental quality standards, emission limit values and other limits and restrictions set in various legislation. Since the various restrictions and environmental quality standards vary in different areas and for various types of activities, then in most cases the significance of impacts are assessed individually in each case. Often the significance of the impact is not only dependent on the type and amount of hazard of the planned action, but also the characteristics of the selected place have an important role. In some cases, the impacts of small objects which do not exceed the allowable thresholds are potentially dangerous if they are planned in a sensitive or congested area; therefore, these projects are applied to the EIA procedure. But at the same time, the relatively large objects with possible impact parameters similar to EIA application volumes may not require application of EIA procedure, because of the optimal choice of location and the projected technology that allows the impacts to be reduced to insignificant levels.

So we can say that the screening is one of the most important and responsible steps in the process of the EIA. A faulty decision could lead to substantial financial loss for the future performance of the project, if an unreasonable decision is made to apply the full environmental impact assessment procedure, which requires substantial investments in both time and finances for the project.

Perhaps even greater losses are possible if technical regulations are not fully prepared because the possible impact is not fully assessed for the proposed action, and the implementation of the project has already started, while not realizing the potential problem situations and risk factors resulting in damage to the environment. It is known that in most cases, the consequences of the negative effects requires more resources and time than measures that could have prevented or reduced the possibility of the caused damage.

\section{The screening of biogas production projects}

Biogas from anaerobic fermentation has several advantages. First of all, biogas is a renewable energy resource. The current power supply globally is dependent on fossil fuels such as crude oil, lignite, coal and natural gas, which are nonrenewable energy resources and the reserves of these resources are being depleted much faster than new ones arise. By contrast, the resulting biogas of the anaerobic fermentation process is a completely renewable resource since the biogas is produced from biomass, which stores the solar energy in the process of photosynthesis. Also the energy production by burning biogas contributes to the national energy sustainability and reduces dependence on imported energy [7].

Similarly, the production of energy by burning biogas is a way to deal with increasing global warming. Here, the essence lies in the fact that the combustion of biogas releases $\mathrm{CO}_{2}$, which is the carbon attracted by plants from the atmosphere in the process of photosynthesis and that is the main difference 
between burning biogas and fossil fuels. In this way, the biogas carbon cycle ends in a very short time.

Biogas from anaerobic fermentation is considered to be an optimal solution for different types of organic waste. The waste is converted into renewable energy and organic fertilizer [7]. Such organic waste as people's household waste, crop residues, animal waste and fertilizers begins a new life cycle in biogas plants. Otherwise this organic waste would have no use and new landfills would need to be built for their storage. After anaerobic digestion the digestate, because of its qualities, serves as a good soil fertilizer. Digestate is rich with nitrogen, phosphorus, potassium and trace elements that can be applied to the soil with conventional liquid manure and slurry equipment. Compared to raw manure the digestate has improved fertilizer efficiency, because it is homogeneous and with more nutrients, the digestate has better carbon / nitrogen ratio and is nearly odourless.

Biogas production benefits the farmers have participated and wider society. The benefits from producing and using the biogas are increased capacity of the local economy, higher employment in rural areas and increasing the region's solvency. Compared to fossil fuels, biogas production with anaerobic fermentation requires a much larger work force to ensure production processes, collection and transportation of anaerobic materials, manufacturing of the equipment, installation, operation and maintenance of biogas plants.

As for the construction of biogas plants, already at its design stage there should be the screening by the law "The Environmental Impact Assessment" annex 2 - "Actions that require a screening". The application of a screening is filed by the owner of the emerging biogas plant in the State Environment Service regional government, which then in accordance with the law "The Environmental Impact Assessment" does the procedure.

In order to ensure environmental compliance in the construction project of the biogas plant, the regional environmental administration issues technical regulations, unless it is found that a full EIA procedure should be applied to the biogas plant during the screening period.

\section{Criteria for assessing the impacts of biogas plants}

Special attention during the EIA of biogas plants should be paid to these the essential criteria: impact on air quality; occurrence of odours; occurrence of noise; impact on soil; impact on water; safety aspects of the station.

\subsection{Impact on the air quality}

Biogas consists mainly of methane, carbon dioxide and water vapour. Biogas composition can be seen in table 1 .

As shown in table 1 the composition of biogas varies. Mainly the biogas composition depends on the type of substrate that has been used for biogas production. Mainly carbon monoxide (CO), which is a product of incomplete 
combustion, and nitrogen oxide compounds $\left(\mathrm{NO}_{\mathrm{x}}\right)$ is emitted while burning the biogas. Both of the mentioned gases are considered greenhouse gases.

Table 1: $\quad$ Biogas composition [8].

\begin{tabular}{|c|c|c|}
\hline Component & Chemical symbol & Content, \% by volume \\
\hline Methane & $\mathrm{CH}_{4}$ & $50-75$ \\
\hline Carbon dioxide & $\mathrm{CO}_{2}$ & $25-45$ \\
\hline Water vapour & $\mathrm{H}_{2} \mathrm{O}$ & $2\left(20^{\circ} \mathrm{C}\right)-7\left(40^{\circ} \mathrm{C}\right)$ \\
\hline Oxygen & $\mathrm{O}_{2}$ & $<2$ \\
\hline Nitrogen & $\mathrm{N}_{2}$ & $<2$ \\
\hline Other compounds & $\mathrm{NH}_{3}$ & $<2$ \\
\hline
\end{tabular}

A certain amount of substances are released into the air from the combustion of biogas in the torch. The torch is used when the biogas yield is greater than intended and it is impossible for additional storage of the biogas. Since biogas combined with the air forms an explosive compound, it cannot be simply blown into the atmosphere; instead the biogas is burned in the aforementioned torch. The design of the torch has to be able to convert methane to reduce incompletely burnt methane and the generation of other products of incomplete oxidation such as carbon monoxide.

Biogas combustion in the torch is considered to be environmentally an unfriendly solution, because the combustion happens without generating energy and, therefore, should only be regarded as a backup solution. Therefore, during the initial evaluation of biogas plants special attention must be paid to the solutions of biogas usage.

According to Latvian law while modelling the air emissions, any available and accepted methods in the world can be used for calculating emissions. That leads to a situation where different companies use different modelling methods of emissions and different emission factors. As a result it is not possible to objectively evaluate the estimated emissions from various plants. In addition, at the moment companies often use emission factors of natural gas during the modelling process, which should be unacceptable because the biogas composition differs from natural gas composition. It is therefore necessary to develop a uniform methodology for calculation and modelling of air emissions of biogas plants.

\subsection{Occurrence of odours}

It is necessary that the substrate is kept in closed containers in order to prevent the occurrence of odours. However odours cannot be completely avoided, which is related to the loading of the substrate in the storage tank. Therefore, an important factor to be considered is the leading wind direction, which certainly should not be directed from the biogas plant to nearby populated areas. Raw biogas contains hydrogen sulphide which has a rotten egg smell and is unpleasant to people. So it is necessary to consider all the risks associated with raw biogas emitted into the atmosphere. In contrast purified biogas is odourless [9]. 
The smell of manure during anaerobic fermentation is reduced by $80 \%$. Digestate after treatment no longer has an unpleasant smell of slurry - it smells more like ammonia [7].

\subsection{Occurrence of noise}

Noise emissions during the biogas production derive mainly from the production machines - air and exhaust fans, the cooler of the mixer and the flue. Similarly, noise also arises from the transport which delivers the raw material to the biogas plant. If most of the noise from the production installations is unavoidable, then relating to noise arising from transport, it can be optimized by planning the transportation of raw materials in daylight. In addition, if the resulting noise from the biogas deliveries of raw materials is not permanent, then, assuming that the biogas plant operates 24 hours a day, the noise from production installations is a constant. In both cases, how to station the location away from the nearest populated area must be taken into account $[7,8]$.

\subsection{Impact on soil}

The end products of the biogas production process are the biogas, which is a fuel gas, and the digestate. Digestate is fermented mass, which is rich in microelements and macronutrients, so it can be used for soil fertilization. The quality of digestate is even better than the untreated slurry. In the case of centralized co-digestion in Latvia farmers receive only the amount of digestate back, which they may use for agricultural fertilizer in accordance with the laws and regulations. The surplus is sold in the particular region to grain growers. In all cases, the digestate is included in fertilizer plants of each farm to replace mineral fertilizers with the digestate.

\subsection{Impact on water}

It is important that raw materials for the biogas production are not present in direct connection with the soil and water. The main reasons for such an event may be insufficient reactor insulation, cracks in storage tanks and the damage of pipes caused by corrosion. Untreated substrate affects groundwater - the quality drops and the pollution increases. Such pollution can lead to various diseases and environmental degradation. Soil and water contamination with raw substrate may cause adverse "slurry vegetation", and increases the risk of spreading pathogens. Related to the issue of quality and protection of groundwater and soil in the life cycle of biogas plants, it occurs 3 different ways:

1. When the station is at the planning stage. The right option of place and technologies (including materials) can solve most of the issues relating to the protection of groundwater;

2. During construction, when a leakage of hazardous substances is possible;

3. In the station operating time when groundwater monitoring is recommended by taking samples to determine the quality changes. 
Also the risks of flooding in the territory should be taken into account. Biogas plants should be planned in a place that has not been flooded in at least the past 30 years [10].

\subsection{Safety aspects of the station}

In permit required for the biogas plant that allows it to run, it is necessary to include an assessment of various preventive and damage control measures in these cases: explosion prevention; fire prevention; mechanical hazards; soundproof design; electrical safety; lightning protection; thermal safety; asphyxiation and poisoning prevention; hygiene and health safety.

Under certain conditions, biogas combined with air forms an explosive gas mixture.

\section{Biogas screening analysis in Latvia}

Till 2007 only 3 biogas plants were running in Latvia with a total installed electricity generating capacity 7,5 $\mathrm{MW}_{\mathrm{el}}$. Since 2009, the number of biogas plants rapidly increased in Latvia. Right now 58 businesses have received a quota for biogas production with a total installed electrical capacity of nearly 54 $\mathrm{MW}_{\mathrm{el}}$.

In April 2011, there were 15 running biogas plants in Latvia with a total electrical capacity close to $19 \mathrm{MW}_{\mathrm{el}}$. These biogas plants are summarized in the table 2 [11].

Table 2: $\quad$ Biogas plants in Latvia until April 2011 [11].

\begin{tabular}{|c|c|}
\hline Source of raw materials & $\begin{array}{c}\text { Installed electrical } \\
\text { power, } \mathrm{MW}_{\mathrm{el}}\end{array}$ \\
\hline Sewage sludge & 1,998 \\
\hline Municipal waste & 5,24 \\
\hline Municipal waste & 0,15 \\
\hline Municipal waste & 0,55 \\
\hline Cattle manure + green fodder & 0,28 \\
\hline Municipal waste & 0,35 \\
\hline Green waste, birds manure & 0,5 \\
\hline Cattle manure, green fodder & 0,996 \\
\hline Cattle manure, green fodder & 0,25 \\
\hline Cattle manure, green fodder & 1,96 \\
\hline Cattle manure, green fodder & 1,96 \\
\hline Cattle manure, green fodder, food factory waste & $0,35(0,7)$ \\
\hline Distillery distilling & 1,9 \\
\hline Cattle manure, green fodder & 2,5 \\
\hline Total: & 18,984 \\
\hline
\end{tabular}


If a classification of Latvia's biogas plants is needed, then they can be classified into 3 groups according to the used substrate:

1. The station, which produces biogas from wastewater treatment;

2. Stations where biogas is produced from the deposited waste of landfills;

3. Stations where livestock and agricultural waste is used for biogas production.

What kind of biogas plants will be built in the future depends on several related factors. State support for electricity production from renewable energy resources (including biogas) is provided by the regulations of the Cabinet of Ministers. The regulations include a number of criteria for electricity producers from biogas to qualify for the mandatory purchase of electricity and ensure that the power producer will be able to sell electricity at a fixed price. When the situation is viewed from this perspective, it would be best for producers to build small plants, as this will provide more profit for each kilowatt hour produced. However, it should be kept in mind that the main criteria that the producer has to use while choosing what kind of station to install remains the availability of the used substrate and possibilities for the usage of produced energy [9].

As for the possible biogas plants in the future there is a great potential for bird and pig farms, as well as regional landfills. Latvia is divided into 11 waste management regions. Despite the development of new landfills, organic fraction is not yet sorted from the stream of municipal solid waste in Latvia. In theory, all regional landfills are potential biogas producers, if the gas is obtained from sorted organic waste [9].

There are many landfill sites in Latvia where biogas production is possible, but the collection system of biogas is not yet built, however the construction of such a system is planned for the future. During the period from 2008 to May 2011 the screening has been performed for 25 projects that have been classified as a biogas plant or a biogas cogeneration plant in Latvia. These projects are summarized and shown in figure 1.

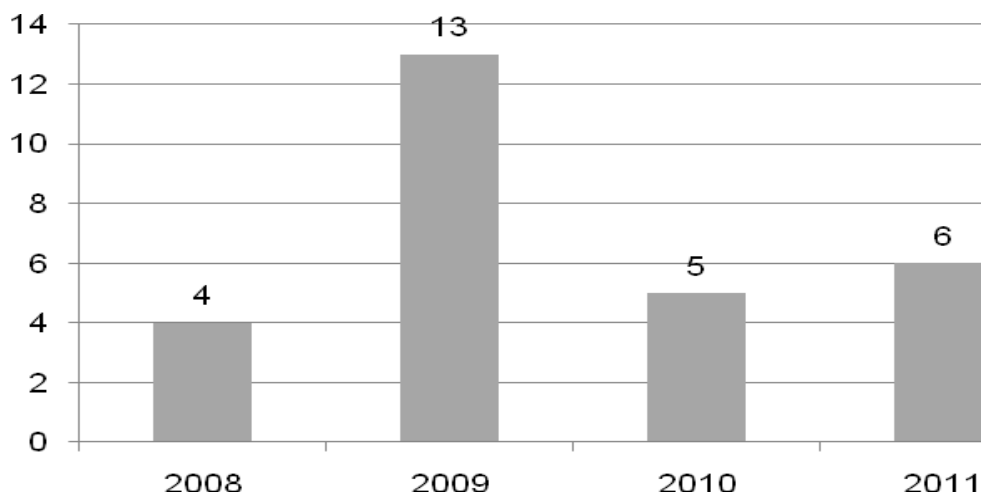

Figure 1: Biogas production projects for which the screening has been made from 2008 to 2011. 
As shown in figure 1 most of the procedures of the screening for biogas projects in the given period were completed in 2009 when the estimated number of projects was 13 .

So far a full EIA procedure has not been applied or taken for any biogas plants. By contrast, an A or B permit of polluting activities has been issued for only 11 projects of biogas cogeneration facilities till now. From these 11 the screening has been completed for only three projects of biogas cogeneration plants.

Not always can the successfulness of a particular biogas plant be assessed according to their individual technical specifications. It is worthwhile to compare technical parameters of planned and already constructed plants. To compare the effectiveness of biogas plants in Latvia the amount of biogas produced from one tonne of waste should be compared. Also a good way to measure the yield of biogas is to compare the amount of biogas produced with the power of cogeneration plants where the produced biogas will be burnt.

\section{The criteria for assessing the significance}

The criteria and their degree of significance related to carrying out the screening of biogas plants in Latvia are given in the table 3.

Table 3: $\quad$ The screening criteria and their significance.

\begin{tabular}{|c|c|c|c|}
\hline & \multicolumn{3}{|c|}{ The significance } \\
\hline Criteria & Insignificant & May be significant & Significant \\
\hline Location & $\begin{array}{l}* \text { Agricultural waste }>5 \\
\mathrm{~km} \\
* \text { The remaining }>15 \mathrm{~km}\end{array}$ & $\begin{array}{l}* \text { Agricultural waste }< \\
5 \mathrm{~km} \\
* \text { The remaining }>15 \\
\mathrm{~km}\end{array}$ & \\
\hline $\begin{array}{l}\text { Energy use } \\
\text { (options for } \\
\text { using produced } \\
\text { energy) }\end{array}$ & $\begin{array}{l}\text { Energy can be used } \\
\text { withinl } \mathrm{km} \text { range }\end{array}$ & $\begin{array}{c}\text { Energy can be used } \\
\text { within more than } 1 \mathrm{~km} \\
\text { range }\end{array}$ & None \\
\hline $\begin{array}{l}\text { Emissions in the } \\
\text { air (estimate) }\end{array}$ & Smaller than reported & Higher than reported & \\
\hline $\begin{array}{c}\text { Reuse of } \\
\text { wastewater }\end{array}$ & $\begin{array}{c}* \text { Wastewater is reused } \\
* \text { Wastewater is treated in } \\
\text { WWTP }\end{array}$ & $\begin{array}{l}* \text { Wastewater is not } \\
\text { treated }\end{array}$ & $\begin{array}{c}* \text { Wastewater is } \\
\text { not treated } \\
\text { (sensitive area) }\end{array}$ \\
\hline Waste & $\begin{array}{c}\text { A contract with the } \\
\text { manager }\end{array}$ & Application to land & $\begin{array}{l}\text { Application to } \\
\text { land (sensitive } \\
\text { area) }\end{array}$ \\
\hline $\begin{array}{l}\text { Odour, storage } \\
\text { of substrate }\end{array}$ & $\begin{array}{l}\text { Leading directions of } \\
\text { wind are taken in } \\
\text { account, location is far } \\
\text { from settlements or } \\
\text { valuable nature objects }\end{array}$ & $\begin{array}{l}\text { Leading directions of } \\
\text { wind are taken in } \\
\text { account, location is } \\
\text { close to settlements or } \\
\text { valuable nature objects }\end{array}$ & $\begin{array}{c}\text { Leading } \\
\text { directions of } \\
\text { wind are not } \\
\text { taken in account, } \\
\text { location is close } \\
\text { to settlements or } \\
\text { valuable nature } \\
\text { objects }\end{array}$ \\
\hline Noise & Far from settlements & Close to settlements & \\
\hline
\end{tabular}


The given criteria include the most important impacts on the environment of biogas plants. The criteria are designed to quickly and successfully carry out the screening of biogas plants.

\section{Conclusions}

The aim of Renewable energy sources by 2020 for Latvia can be achieved, if energy efficiency of user energy resources is ensured and energy sources are constructed, where fossil fuel is replaced with the renewable one.

In the past years the number of procedures of EIA applied to biogas projects has increased. It is necessary to implement a systems approach in the procedure of EIA.

It is necessary to elaborate common approach for EIA of biogas projects. For establishing and describing the impacts and degree of significance related to carrying out the screening of biogas plants, the set criteria can be used.

For projects that are subject of EIA procedure, life cycle analyses must be done.

\section{Acknowledgement}

This work has been supported by the European Social Fund within the project "Support for the implementation of doctoral studies at Riga Technical University".

\section{References}

[1] Toro, J., Requena, I. and Zamorano, M., Environmental impact assessment in Colombia: Critical analysis and proposals for improvement. Environmental Impact Assessment Review, 30, 2010.

[2] Kornov, L. and Prapaspongsa, T., Environmental Impact Assessment II, Aalborg University: Aalborg, 2011.

[3] Koornneef, J., Faaij, A. and Turkenburg, W., The screening and scoping of Environmental Impact Assessment and Strategic Environmental Assessment of Carbon Capture and Storage in the Netherlands. Environmental Impact Assessment Review, 28, 2008.

[4] Pinho, P., McCallum, S. and Cruz, S., A critical appraisal of EIA screening practice in EU Member States. Impact Assessment and Project Appraisal, 28, 2010.

[5] Pubule, J., Blumberga D. and Romagnoli F., et. al. Analysis of the environmental impact assessment of power energy projects in Latvia. Management of Environmental Quality: an International Journal, 23 (2), 2012.

[6] Wood, G., Thresholds and criteria for evaluating and communicating impact significance in environmental statements:'See no evil, hear no evil, speak no evil'?. Environmental Impact Assessment Review, 28, 2008. 
86 Environmental Impact

[7] Daublein D. and Steinhauser A. Biogas from Waste and Renewable Resources. An Introduction. Second, Revised and Expanded Edition. Weinheim: WILLEY-VCH, 2011.

[8] Blumberga D., Veidenbergs I., Romagnoli F et.al.. Bioenerğijas tehnologijas. Madonas Poligrafists: Madona.

[9] Blumberga D., Dzene et. al. Biogas. Handbook. 2011.

[10] Kossman W., Pönitz. and Hebermehl S, Biogas Digest. Volume II. Biogas Application and Product Development. GTZ, 1999.

[11] Karklins., A. Review of Latvian biogas market. Future plans. Proceeding of 4th Latvian green energy forum, RTU: Riga, 2011. 